\title{
Effect of supplementing various proteinaceous cakes on milk yield, milk composition and feed intake of lactating Damani goats
}

\author{
Muhammad Zeeshan ${ }^{1 *}$, Sayeda Adia Fatima ${ }^{2}$, Shakeeb Ullah ${ }^{1}$, Umer
} Farooq $^{1}$ and Saqib Ali ${ }^{1}$

1. Faculty of Veterinary and Animal Sciences, Gomal University Dera Ismail Khan, Pakistan

2. Department of Poultry Production, Faculty of Animal Husbandry and Veterinary Sciences, University of Agriculture Peshawar, Pakistan

*Corresponding author's email: zeeshankhan28773@gmail.com

Citation

Muhammad Zeeshan, Sayeda Adia Fatima, Shakeeb Ullah, Umer Farooq and Saqib Ali. Effect of supplementing various proteinaceous cakes on milk yield, milk composition and feed intake of lactating Damani goats. Pure and Applied Biology. Vol. 11, Issue 1, pp169-174. http://dx.doi.org/10.19045/bspab.2022.110018

\begin{tabular}{llll}
\hline Received: 25/02/2021 & Revised: 23/04/2021 & Accepted: 06/05/2021 & Online First: 21/05/2021 \\
\hline
\end{tabular}

\section{Abstract}

The work was designed to elucidate the effects of supplementation of proteinaceous cakes on the milk composition, its yield and feed intake. Twelve Damani goats of similar body weight, lactation numbers and age were choose and divided into 4 groups. Trial duration was one month. Animals were graze for six hours/day and were provided with maize fodder and straw in the evening i.e. control diet, while other three groups were offered with cakes in addition to the control diet on iso-nitrogenous basis including cotton seed cakes (Diet-CSC), mustard seed cakes (Diet-MSC) as well as maize oil cakes (Diet-MOC). Milk yield as well as feed intake data was taken daily. Each week from four consecutive milking samples were taken for milk composition analysis. Feed intake (kg/day) was $4.63 \pm 0.02$ observed for Diet-CSC and was the maximum $(\mathrm{P}<.0001)$ among all diets while least feed intake was recorded for control diet. Milk yield (ml/day) for Diet-CSC was noted $1080 \pm 4.68$ and was the highest $(\mathrm{P}<.0001)$ while $1008 \pm 4.68,966 \pm 4.68$ and $887 \pm 4.68$ was recorded for Diet-MOC, Diet-MSC as well as control group. Maximum $(\mathrm{P}<.0001)$ fat in milk was noted for Diet-CSC $4.81 \pm 0.03 \%$ while minimum was noted for control diet $4.20 \pm 0.03 \%$. Maximum $(\mathrm{P}<.0001)$ milk protein for Diet-CSC was recorded $3.72 \pm 0.01 \%$. As offered cakes are easily available and economical source of protein so our main aim was to check that how they can affect the production of goats in terms of milk yield, milk fat and feed intake. So our conclusion was that their supplementation has overall positive effects.

Keywords: Cotton seed cake; Diet; Maize oil cake; Mustard seed cake; Supplementation \section{Introduction}

Huge population (191 million) of animals are facing shortage of green fodders. This shortage of green fodder is met by crop residues, natural grasses as well as byproducts wastes in which the level of crude protein is low while the fiber and lignin fractions are high [1]. Fulfillment of dietary requirements of livestock with high fiber feed resources can greatly affect the animal productivity [2]. To enhance the production of small polygastrics a balance between energy as well as protein is required [3]. International Dairy Federation 
in year 2017 ranked Pakistan at number four in the world for milk production. Milk is mainly obtained from cattle and buffalo however small ruminants also have an excellent contribution in milk production i.e. goats yield almost 851 thousand ton of milk in a year. Its share in national production is 2.5 percent approximately 2.5 $\%[4,5]$. Goat is a small poly gastric animal and is considered as the best among other small poly gastric animals due to its manner of grazing as well as its GIT which works efficiently in scarcity seasons. 4.1 is the lactose percentage of goat milk while 4.7 is that of cow milk, it is therefore people having lactose intolerance can use goat milk. $\mathrm{Ca}, \mathrm{P}$ and $\mathrm{K}$ minerals in goat milk are more as compare to cow milk [6]. In the ration of large poly gastric animals proteinaceous cakes are being used conventionally, though in small poly gastric animals these cakes are not generally used [7]. Rapid growth rate, less methane production in the rumen while increased production of the propionic acid, minimizing energy losses as well as causing greater efficiency of utilization of the nutrient finally results in high milk yield [8]. Proteinaceous cakes supplementation is not only advantageous on palatability, digestibility and amino acids nutritional balance point of view but is also cheapest supplemental source of protein [9]. Major aim of our work was to explore the outcomes of supplementation of various proteinaceous concentrates on yield as well as compositional profile of milk and feed intake in lactating Damani goats.

\section{Materials and methods}

Departmental Ethical committee permitted the current study.

\section{Experimental design}

12 lactating Damani goats were selected i.e. of same age as well as lactation number. These selected were distributed into 04 dietary groups $(n=3)$ on the basis of milk yield, age, lactation number as well as body weight.

\section{Experimental ration}

All animals were allowed to graze for six hours per day, in addition to this they were offered with maize fodder (chopped with piece size 1-2 inches ) as well as wheat straw adlibitum (control diet) animals of other three groups were offered with control diet plus supplements i.e. cotton seed cake 300 grams per day and the group was named Diet CSC, 212 gram per day was the mustard seed cake and this particular group was named Diet MSC last group was given with maize oil cake at the rate of 416 gram in a day, the group was named as Diet MOC on iso-N basis. Those supplements contributed nearly $40 \%$ of total nutrient supplies [10]. During trail fresh drinking water was accessible to the goats round the clock.

\section{Experimental trial}

Trail duration was set 30 days with first 7 days were given as an adaptation period and remaining 23 days were the experimental period. During trail milk composition, feed intake and milk yield were checked that how the supplementation affects them. Data was collected for feed offered, grazing time and feed refused.

\section{Collection, preservation and} transportation of feed and milk samples In each week maize fodder, proteinaceous cakes, grazing pasture, feed refused sampling was completed. For compositional analysis of milk out of four successive milking in each week samples were collected in clean labelled sample tubes and were immediately transferred to VRI Dera Ismail Khan in box with ice pack, where milk compositional analysis was done through using lacto scan.

\section{Results}

\section{Chemical Composition of different feed ingredients}

In addition to grazing, maize fodder as well as wheat straw were given as a basal diet. Except control group animals of treatment groups were fed with cotton seed cake, maize oil cake as well as mustard seed cake. Proximate analysis including DM, Moisture, Ash, CP, CF and EE [11] of feed 
stuff samples were executed in the Animal nutrition laboratory of Animal and Poultry Production Department of Faculty of
Veterinary and Animal Sciences Gomal University. DM Proximate composition of given feed is in (Table 1).

Table 1. DM basis proximate composition of feed stuff

\begin{tabular}{|c|c|c|c|c|c|}
\hline $\begin{array}{c}\text { Proximate } \\
\text { composition (\%) }\end{array}$ & $\begin{array}{c}\text { Wheat } \\
\text { Straw }\end{array}$ & $\begin{array}{c}\text { Cotton seed } \\
\text { cake }\end{array}$ & $\begin{array}{c}\text { Maize oil } \\
\text { cake }\end{array}$ & $\begin{array}{c}\text { Maize } \\
\text { Fodder }\end{array}$ & $\begin{array}{c}\text { Mustard seed } \\
\text { cake }\end{array}$ \\
\hline CP & 3 & 23.5 & 16.6 & 9.7 & 32.4 \\
\hline DM & 90.6 & 91.8 & 94.6 & 23.7 & 91.7 \\
\hline EE & 0.1 & 8.9 & 12.2 & 1.8 & 9.7 \\
\hline CF & 41.8 & 27.5 & 9.3 & 27.2 & 9.4 \\
\hline ASH & 10.9 & 6.8 & 1.6 & 9.9 & 1.7 \\
\hline
\end{tabular}

\section{Milk yield and feed intake}

Feed intake as well as milk yield record is briefed in (Table 2). Total Intake of animals offered with Diet-CSC was recorded maximum $(\mathrm{P}<0.001) 4.63 \mathrm{~kg}$ per day. Next to this was for the animals offered with Diet-MOC and Diet-MSC and feed intake recorded for them was $4.51 \mathrm{~kg}$ and $4.33 \mathrm{~kg}$ per day respectively. Animals offered with control diet had minimum feed intake 4.17 $\mathrm{kg}$ per day. Feed intake record for animals supplemented with proteinaceous cakes was higher as compare to animals offered with control diet only. Statistically intake was significantly different $(\mathrm{P}<0.001)$ for all offered diets. For Diet-CSC offered animals milk yield was recorded maximum $(\mathrm{P}<0.001)$ among all the groups. $1080 \mathrm{ml}$ was the per day milk yield of goats offered with Diet-CSC. Diet- MOC as well as DietMSC animals' milk yield was $1008 \mathrm{ml}$ and $966 \mathrm{ml}$ respectively while $887 \mathrm{ml}$ the lowest milk yield and was observed for control group animals. Milk yield was significantly changed $(\mathrm{P}<0.001)$ for all given diets and also yield was noted higher for groups offered with protein supplements.

Table 2. Effects of oilseed cakes on feed intake and milk yield

\begin{tabular}{|c|c|c|}
\hline Diet & Feed Intake (kg/day) & Milk Yield (ml/day) \\
\hline Control & $4.17^{\mathrm{d}}$ & $887.9^{\mathrm{d}}$ \\
\hline Diet-CSC & $4.63^{\mathrm{a}}$ & $1080^{\mathrm{a}}$ \\
\hline Diet-MSC & $4.34^{\mathrm{c}}$ & $966^{\mathrm{c}}$ \\
\hline Diet-MOC & $4.51^{\mathrm{b}}$ & $1008^{\mathrm{b}}$ \\
\hline SEM & 0.02 & 4.68 \\
\hline P Value & $\mathrm{P}<.0001$ & $\mathrm{P}<.0001$ \\
\hline
\end{tabular}

\section{Milk composition}

In (Table 3) data for milk composition is briefed. Uppermost $(\mathrm{P}<0.001)$ milk fat contents were noted for Diet-CSC $4.81 \%$. Goats fed with Diet-MOC had $4.63 \%$ whereas Diet-MSC milk fat was $4.50 \%$. Similarly, $4.20 \%$ milk fat the minimum among all was noted for control diet. $3.72 \%$ was the noted milk protein for Diet-CSC and was the maximum $(\mathrm{P}<0.001)$ among all groups. $3.67 \%$ and $3.60 \%$ were observed milk protein of animals given with DietMOC and Diet-MSC respectively. For control diet $3.48 \%$ the minimum milk protein was noted. On statistical grounds supplementation of proteinaceous cakes affects milk fat as well as on milk protein significantly $(\mathrm{P}<0.001)$. Milk lactose contents were noted statistically not significant $(\mathrm{NS})(\mathrm{P}>0.001)$ however their percentage recorded for various dietary groups i.e. $4.61 \%$ for Diet-MOC, $4.56 \%$ for Diet-CSC, $4.58 \%$ for Diet-MSC and $4.54 \%$ for control diet. $8.83 \%$ the maximum $(\mathrm{P}<0.001)$ solid not fat $(\mathrm{SNF})$ in milk was noted for Diet-CSC. Diet-MOC SNF was 
$8.76 \%$ and SNF for Diet-MSC was $8.62 \%$.

SNF for control diet was $8.57 \%$ the lowest among all.

Table 3. Effect of oilseed cakes on milk composition

\begin{tabular}{|c|c|c|c|c|}
\hline \multirow{2}{*}{ Diet } & \multicolumn{4}{|c|}{ Milk Constituents (\%) } \\
\cline { 2 - 5 } & Fat & Protein & Lactose & SNF \\
\hline Control & $4.20^{\mathrm{d}}$ & $3.48^{\mathrm{d}}$ & 4.54 & $8.57^{\mathrm{d}}$ \\
\hline Diet-CSC & $4.81^{\mathrm{a}}$ & $3.72^{\mathrm{a}}$ & 4.56 & $8.83^{\mathrm{a}}$ \\
\hline Diet-MSC & $4.50^{\mathrm{c}}$ & $3.60^{\mathrm{c}}$ & 4.58 & $8.62^{\mathrm{c}}$ \\
\hline Diet-MOC & $4.63^{\mathrm{b}}$ & $3.67^{\mathrm{b}}$ & 4.61 & $8.76^{\mathrm{b}}$ \\
\hline SEM & 0.033 & 0.010 & 0.112 & 0.013 \\
\hline P Value & $\mathrm{P}<0.001$ & $\mathrm{P}<0.001$ & $\mathrm{NS}$ & $\mathrm{P}<0.001$ \\
\hline
\end{tabular}

\section{Discussion}

According to our observations feed intake was improved with supplementation of proteinaceous cakes. Maximum feed intake was noted for goats offered by Diet-CSC and reason behind this is perhaps the palatability of cotton seed cakes. [12] Observations were same as we noted in our experiments that cotton seed cakes (CSC) in addition with mustard seed cakes (MSC) when offered their outcomes regarding feed intake were positive. It was also proved by them that feed intake was improved as the level of CSC was raised in the diet. [13] According to his findings with offering of energy as well as proteinaceous supplements the basal diet intake was increased. [14] In his experiment judged that with elevation of level of proteinaceous concentrates in the ration of animal the roughage intake was enhanced. According to [15] CSC is not only palatable but is also a good appetizer and perhaps this is the reason that dry matter intake was enhanced when CSC was used as a proteinaceous supplement, As the total digestible nutrients, minerals as well as the nitrogen are generally little in the basal diet based on forages so in such circumstances provision of proteinaceous supplements can not only increases the total dry matter intake but can also fulfil the nutrients deficiencies. $4.81 \%$, $4.63 \%$ and $4.50 \%$ are the noted values of milk fat contents for Diet-CSC, Diet-MOC and Diet-MSC respectively and according to our findings with proteinaceous supplementation the milk fat contents were also increased. [16] Noted in his studies that use of CSC as proteinaceous supplements has enhanced effects on milk fat contents in Dwarf Red Sokoto. [17] In final results of his research trial on dairy cows he concluded that supplementation of CSC can significantly $(\mathrm{P}<0.05)$ improved the fat contents of milk. [18] In dairy cows the SNF contents of milk were not affected with the supply of proteinaceous supplements in the feed. Goats provided with Diet-CSC has $1080.0 \mathrm{ml}$ per day milk yield recorded and it was the highest milk yield among all while $887 \mathrm{ml}$ per day was noted milk yield of control group and was the lowest milk yield recorded among all groups. [19] Also observed the outcomes same like us that Proteinaceous cakes when used in the diet can have positive impact on yield, fat as well as protein contents of milk. [20] also supported our results regarding milk yield he observed that cows fed with $35 \%$ CSC has higher levels of milk yield. [17] Who narrated that milk yield was significantly improved with the diet having higher level of CSC. [21] Also got results like us he noted that milk production was significantly increased for those animals whose ration contain 50 percent CSC.

\section{Conclusion}

Through recent work it is evident that agroindustrial byproducts when use in the diet of Damani goats as an economical protein source like cotton, mustard as well as maize oil cakes have considerably improve the 
milk yield. Supplementation also has beneficial effects on total feed intake as they are high palatable similarly milk fat as well as milk protein contents were also improved. So we recommend the use of above proteinaceous cakes in the diet of small ruminants for better health and production.

\section{Author's contributions}

Conceived and designed the experiments: $M$ Zeeshan, SA Fatima, Performed the experiments: M Zeeshan, S Ullah, Analyzed the data: U Farooq, SA Fatima, Contributed reagents/materials/analysis tools: M Zeeshan, $\mathrm{S}$ Ali, Wrote the paper: M Zeeshan

\section{References}

1. Belibasakis D \& Tsirgogianni (1995). Effects of whole Cottonseeds on milk yield, milk composition and blood components of dairy cows in hot weather. J of Anim Feed Sci Tec 52: 227-235.

2. Sarwatt SV, Milang MS, Lekule FP \& Madalla (2004). Moringa oleifera and cotton seed cake as supplements for small holder dairy cows fed Napier grass. J of livestock res. for rural development 16: 113.

3. Mendietta, ABR, Sporndly NR, Sanchez E \& Sporndly (2011). Moringa oleifera leaf meal as a source of protein in locally produced concentrates for dairy cow fed low protein diets in tropical areas. J of livestock Sci 137: 1017.

4. Ali Q (2006). Goats undervalued assets in Asia. The aphca-ili regional workshop on goat production systems and markets, Luang Prabang. Lao PDR 47-49.

5. Anonymous (2008). Pakistan Economic Survey Government of Pakistan Ministry of Finance Economic Advisory Wing Islamabad.

6. Silanikove, Leitner G, Merin U \& Prosser (2010). Recent advances in exploiting goat milk quality, safety and production aspects. $J$ of Small Rumi Reso 89: 110-124.
7. Sarwar, Khan MA \& Iqbal (2002). Feed resources for livestock in Pakistan. $J$ of Agri Bio 4: 186-192.

8. McDonald P, Edward RA Green JF \& Morgan CA (1996). Animal nutrition long man scientific and technical, Harlow, UK.

9. Luka J \& Kibon (2014). Milk Production of Red Sokoto goats fed with Supplements in Bauchi State Nigeria. J of Anim Reso 2(8): 258-263.

10. NRC (2007). Nutrient Requirements of Large Ruminants. National Academy Press, Washington, DC.

11. AOAC (1990) Official Method of Analysis, Association of Official Analytical Chemists, Washington, DC.

12. Uddin HA, Rehman, Khan R, Bakhat DK, Farid K, Khrshaid A, Ullah S \& Ali Z (2013). Effect of Cotton seed cake on cattle milk Yield and composition at livestock research and development Station Surezai Peshawar Pakistan. Pak J of Anim Nutrition 12: 468-475.

13. Adu IF (1982). Effects of energy and protein levels on feed intake and nutrient utilization by Yankasa Lambs. Niger J of Anim Production 9 (2): 90 93.

14. Ikhatua UJ \& Olubajo FO (1979). Studies on Protein requirement of steers. Nitrogen balance studies with three breeds of cattle maintained on all roughage supplemented diets. Niger $J$ of Anim Production 6: 88 - 93.

15. Yasmeen R, Ahmad N, Habib G, Saleem M, Rehman \& Rahman AU (2007). Substitution of traditional concentrate with Grewia Oppositifolia leaves in sheep. Sarhad J of Agri 23: 493-500.

16. James IJ \& Osinowo AO (2004). Changes in Udder size and live weight of West African Dwarf Red Sokoto and Sahel goats during lactation and their phenotypic relationship with partial daily milk yield. Niger $J$ of Anim Production 31(1): 119 - 129. 
17. Grings E, Roffler RE \& Deitelhoft DP (1991). Response of dairy cows in early lactation to addition of Cotton seed meal Alfalfa based diets. J of Dairy Sci 74: 2580-2587

18. Cezarry PB, Pysera D, Minakowski A, Sederevicius \& Traidaraite (2005). Composition of milk and blood metabolites in high productivity dairy cows on pasture. M.Sc. thesis. Deptt of Anim. Nutrition \& feed management, Uni. Warmia \& MaZury Olsztyn.

19. Noftsger SM, Hopkus BA, Diaz DE, Brown \& Whitelow LW (2000). Effect of whole and expanded-expelled
Cotton seed on milk yield and blood gossypol. J of Dairy Sci 83(11): 2539 2547.

20. Kunju PJ, Mehta AK \& Garg MR (1992). Feeding of bypass protein to crossbred cows in India on straw based ration. American J of Anim Sci 5: 107112.

21. Bade RN, Kank VD, Patil MD, Gadegaonkar GM, Jagadale SD \& Phondba BT (2008). Effect of replacement of cottonseed cake with sunflower extraction on lactation performance of cows. $J$ of Anim Nutrition \& Feed Tech 8: 279-284. 